DEUİFD XLVI / 2017, ss. 221-251.

\title{
İSVEÇ’TE DİN VE DEVLET İLİŞKİLERINIIN SEKÜLERLEŞME BAĞLAMINDA İNCELENMESİ
}

\begin{abstract}
Seray KILIÇ*
ÖZ

1593 yllındaki Uppsala Meclisi ile Evanjelik Lüteryen öğretiyi resmi din olarak kabul eden İsveç Krallığı, XVIII. yüzyıldan itibaren uyguladığı reformlar ile din ve devlet ilişkileri bağlamında tarafsızlık politikasına doğru ilerlemiştir. 2000 yılında alınan bir kararla devlet ve İsveç Kilisesi arasındaki resmi bağın sona ermesi bu anlamda önemli bir adım olarak kabul edilmekle birlikte dini örgütlere ilişkin yasal düzenlemeler ve bu örgütlerin toplumsal yapılanma içindeki konumu hala tartışılmaktadır. Bu çalışmanın amacı İsveç'te din ve devlet arasındaki ilişkileri, tarihsel gelişimini ve mevcut durumunu, sekülerleşme kuramı bağlamında incelemektir. Yasalar, komisyon raporları ve yazındaki diğer çalışmalar üzerinden yapılan inceleme neticesinde İsveç'in üç nedenle kendine özgü bir vaka olduğu anlaşılmaktadır. İlk olarak, İsveç'teki mevcut durum uzun yıllar süren, siyasi ve dini otoriteler arasındaki müzakerelerin neticesidir. İkinci olarak, bu reform süreci dini ve siyasi otoriteler arasındaki güç paylaşımı üzerinden değil demokratik bir devletin unsuru olarak inanç özgürlüğü temelinde yürütülmüsstür. Son olarak, İsveç Kilisesi ile devlet arasındaki ayrillğı̆n fiilen ve tam anlamıla gerçekleşmediği, bu iki otorite arasındaki ilişkinin hala muğlak olduğu görülmüştür. Bu durum, geleneksel dini pratiklerin toplumsal yapı içindeki işlevselliğinin geçerliliğini korumasından ileri gelmekte olup İsveç’i sekülerleşme kuramı içinde kendine özgü bir yere koymaktadır.
\end{abstract}

Anahtar Kelimeler: İsveç, Kilise, Sekülerleşme, Din-Devlet İlişkileri, İnanç Özgürlüğ̈̈.

\section{SECULARIZATION THEORY AND ANALYSIS OF RELIGION AND STATE RELATIONS IN SWEDEN}

\section{ABSTRACT}

Tightly bounded with the Evangelic Lutheran Church since the Uppsala Convocation in 1593, the Kingdom of Sweden has constantly moved to a more

\footnotetext{
* Arş. Gör., DEU Sosyal Bilimler Enstitüsü Avrupa Birliği ABD. seray.kilic@,deu.edu.tr

Makalenin Hakemlere Gönderiliș Tarihi : 06/10/2017

Makalenin Hakemlerden Geliș Tarihi : 22/11/2017
} 
neutral attitude in terms of religion-state relations since the XVIII. century. Although the separation of state and the Church of Sweden in 2000 is seen as an ultimate step in this sense, the legal status of the religious organizations and their positions in the social structure is still debated. This paper aims to analyse historical evolution and current situation of religion-state relations in Sweden with reference to secularisation theory. Based on the review of legislative reports, legal documents and the literature, the paper argues that Sweden is a sui generis case in the literature for three reasons. First, existing relation between the state and the Church of Sweden is the outcome of a centuries-long democratic process in which political and religious authorities engaged in a series of negotiations and nurtured the existing model within that time. Second, the motivation behind changing religion-state relations in Sweden was not only about power sharing between religious and civil authorities, but rather about ${ }^{3}$ freedom of religion in a democratic society. Finally, it is still possible to conclude that the separation is not an absolute one and the relation between the state and the Church of Sweden is ambiguous. This brings us to the fact that religion still has a functional power within the social structure to considerable extent, which puts Sweden in a distinctive place with regards to the secularisation theory.

Keywords: Sweden, Evangelic Lutheran Church, Secularism, Religion-State Relations, Freedom of Religion.

\section{Giriş}

İsveç -resmi adıyla İsveç Krallığı- anayasal monarşiyle yönetilen aynı zamanda parlamenter sisteme sahip bir devlettir. Refah devleti uygulamaların yaygın olduğu İsveç, din-devlet ilişkisi ve dinin toplumsal yaşamdaki etkisi söz konusu olduğunda seküler devletler arasında siralanmaktadir.

XII. yüzyılda Katolik mezhebin merkezlerinden biri olan İsveç, XVI. yüzyıla doğru, Hristiyanlık içinde reformist hareketlerin başlamasıyla birlikte, Protestanlığın kalelerinden biri haline gelmiştir. İlerleyen yıllarda devlet Lüteryen inanış ile sıkı bir bağ oluşturmuş ve bunu XX. yüzyllın ortalarına dek sürdürmüştür. 1 Ocak 2000 tarihinde yürürlüğe giren yasayla İsveç Evanjelik Lüteryen Kilisesi'nin resmi kilise statüsüne son veren ülke, bu yönüyle diğer İskandinav ülkelerinden ayrılmaktadır. Kilise'nin ${ }^{1}$ yanında diğer dini toplulukları da resmi olarak

1 Metnin devamında "İsveç Kilisesi” ve "Kilise" birbirinin yerine kullanılmıştır. 
tanıyan İsveç, yasal olarak bu topluluklara karşı eşit muamele ilkesini benimsemiştir. Dinin siyasal alanda azalan gücü ve dini toplulukların toplumsal yapıdaki statüsüne ilişkin çoğulcu politikalar bakımından değerlendirildiğinde İsveç’te din ve devlet ilişkilerinin gelişiminin sekülerleşme kuramının varsayımlarını doğrular nitelikte olduğu kanaati uyanmaktadır.

Bu çalışmanın amacı İsveç’in din ve devlet ilişkilerinin tarihsel gelişimini sekülerleşme kuramı bağlamında incelemektir. Bu kapsamda yasalar, Meclis ve ilgili komisyon raporları, yasa teklifleri gibi resmî belgeler üzerinden yapılan incelemelerin yanı sıra yazındaki çalışmalardan yararlanılmıştır. Çalışma dört bölümden oluşmakta olup ilk bölümünde İsveç’teki gelişmelerin incelendiği bağlam olarak sekülerleşme kuramına değinilmiştir. İkinci bölümde din ve devlet ilişkilerinin bugünkü yapısını etkileyen dinamikleri anlayabilmek amacıyla tarihsel süreçten bahsedilmiştir. Üçüncü ve dördüncü bölümlerde ise İsveç’te Kilise ve diğer dini örgütlere ilişkin güncel yasal düzenlemeler ile bu örgütlerin, devletin de desteğiyle, toplumsal düzende sahip oldukları konumları üzerinden devletle olan ilişkileri incelenmiştir. Yapılan değerlendirme neticesinde İsveç'in sekülerleşme yazını içinde istisnai bir yere sahip olduğu anlaşılmıstır.

\section{Sekülerleşme Kuramına Bakış}

Sekülerleşmeyi birden fazla anlamda ele almak mümkündür. Casanova'ya göre sekülerleşme modern toplumlarda dini inancın ve buna dayalı pratiklerin önemini kaybetmesi olarak ele alınabileceği gibi yine liberal toplumlarda daha fazla görülen dinin özel alanla sinırlı kalmasi; devlet işleri, ekonomi ve bilimsel faaliyetler gibi sivil alanların dinin etkisinden siyrilması olarak da kullanılabilmektedir. ${ }^{2}$

"Sekülerleșme" kavramının Latince saeculum kelimesine dayandığ1 ve bu kelimenin, bilhassa IV. ve V. yüzyıllarda, "dünya" anlamında kullanıldığı tahmin edilmektedir. Kökü itibarıly dünyevi işlere ilişkin bir kavram olarak kullanılmaya başlanan bu kelime zaman içinde dinsel öğretilerin ve düzenlemelerin etkili olduğu alanlar ile sivil alanları

2 José Casanova, "Rethinking Secularization: A Global Comparative Perspective", The Hedghog Review, Bahar-Yaz, Say1 8, 2006, s.7. 
ayırt etmek için kullanılmıştır. ${ }^{3}$ Sekülerleşmenin bugünkü anlamını kazanmas1, Rönesans ve Reform hareketlerinin etkisiyle sivil otorite (devlet) ve dini otorite (kilise) arasındaki çatışma ve bunu takip eden ayrilıklar üzerine olmuştur. Sekülerleşme bu dönemde toplumsal ve siyasi çalışmaların odağı haline gelmiştir. Bu çalışmalara imza atan düşünürlerin arasında sekülerleşme kavramının gelişimini en fazla etkileyen şüphesiz Alman sosyolog Max Weber olmuştur. Sekülerleşme kavramını doğrudan kullanmamış olsa da Weber, din(ler) sosyolojisine ilişkin görüşleri ve rasyonaliteyi (akılc1lı̆̆1) temel alan açıklamalarıyla sekülerleşmenin ilk kuramcılarından sayılmaktadır. Weber'e göre XVI. yüzyılın başlarına dek dünyadaki her şeyi dini öğretiler doğrultusunda algılayan ve açılayan halklar, kapitalizmle birlikte hayatlarına egemen olmaya başlayan eşitsizlik ve bunun yarattığ1 huzursuzluk nedeniyle, egemen olan bu "gizemli" toplumsal örgütlenmeyi sorgulamaya başlamış ve akılc1lık yükselişe geçmiştir. ${ }^{4}$ Dolayısıyla Weber'e göre sekülerleşme hem bu sorgulamanın ve kopuşun yaşandiğ1 süreç hem de akılcıllğın yarattığ1 sonucun kendisidir. ${ }^{5}$

Günümüzde din ve devlet ilişkilerinin açıklayan hâkim yazın ise 1960-1970 aralığında ortaya konan sekülerleşme kuramına ilişkin çalışmalardan oluşmaktadır. Acquaviva, Luckmann ve Wilson gibi sosyologlar dinin toplumsal hayattaki yerine, özel olarak Hiristiyanlığın ve Kilise'nin konumuna, ilişkin çalışmalarıyla bu alana önemli katkıda bulunmuşlardır. Bu çalışmaların çoğu modern toplumda dinsel pratiklerin toplumsal örgütlenmedeki öneminin giderek azaldığı; dinin bireyin pratiklerinde ve özel alanla sinırlandığına ve hatta "görünmez" olduğuna ilişkin ortak bir kanata sahiptir. ${ }^{6}$ Dinin azalan öneminin nedenleri ise farklı görüşlerle açıklanmıştır. Örneğin Wilson rasyonalizmi temel alan bir sekülerleşme olgusundan bahsederek Weber'in izini takip etmiş ve

3 William H. Swatos, Jr. and Kevin J. Christiano, "Secularization Theory: The Course of a Concept", Sociology of Religion, Cilt 60, 1999, s.211.

4 Michale W. Hughey, "The Idea of Secularization in the Works of Max Weber: A Theoretical Outline”, Qualitative Sociology, Cilt 2, Say1 1, 1979, s.86.

5 Swateos ve diğerleri, s.212.

6 Karel Dobbelaere, "Some Trends in European Sociology of Religion: The Secularization Debate”, Sociological Analysis, Cilt 48, Say1 2, 1987, s.111. pp. 107-137 
dini inancin genel olarak toplum üzerindeki etkisinin, kontrol gücünün azaldığını ifade etmiştir. Bireyleri bir araya getiren ve toplumsal örgütlenmeyi kolaylaştıran bir unsur olarak dinin yerini modern çağa ait kavramların aldığını ifade eden Wilson, günümüzde dine ait olan unsurların gönüllügün esas olduğu özel alanla sinırlandırıldığ1 ve hatta marjinalleştiğini söylemektedir. ${ }^{7}$ Luhmann ve D. Martin gibi işlevselci bir bakış açısıyla sekülerleşmeyi ele alanlar ise dinin toplumsal hayatı düzenleyici etkisini vurgulayarak "işlevselciliğin yüksek düzeyde yaşandığ1 kültürlerde" dinsel ritüellerin yerini devletin ve diğer sivil örgütlerin kontrolüne bıraktığını söylemektedir ${ }^{8} \mathrm{Bu}$ noktada, çalışmanın kavramsal bağlamını da dikkate alarak, bir otorite olarak kiliselerin veya diğer dini örgütlenmelerin yerine dair argümanlara da yer vermek gerekmektedir. Örneğin, sekülerleşmeye ilişkin çalışmalarda esas odak noktasının otorite kavramı olduğunu vurgulayan Chaves, dini kurumların azalan gücüyle ilgili çalışmaların modern hareketler için daha açıklayıcı olacağını söylemiştir. Chaves'e göre hâkim literatürde yeterince dikkate alınmayan ancak din-devlet ilişkilerinin gelişimini açıklamak bakımından son derece önemli olan kavram laikleşme (laiciz̧ation) yani dini kurumların sosyal ve siyasi yap1 üzerindeki otoritesinin azalmasıdır. Buna göre, bireylerin yerleşik dini örgütlerle olan bağını veya yeni yeni gruplara olan eğilimine gereğinden fazla odaklanmak ve sekülerleşme tartışmalarını bu düzlemde yürütmek esas devinimi kaçırmamıza neden olmaktadır. ${ }^{9}$ Bu doğrultuda, çalışmaya konu olan İsveç örneğinde olduğu gibi, devlet ile dini otorite arasındaki ilişkinin gelişimini ve sosyopolitik bağlamda ilişkilerin mevcut durumunu irdelemek sekülerleşmeyi anlamanın en temel aracı olmaktadır.

\section{Din ve Devlet İlişkilerinin Tarihsel Gelişimi}

Günümüzde nüfusunun \%62'si Evanjelik Lüteryen İsveç Kilisesi'ne bağlı olan İsveç halkı Hristiyanlıktan evvel mitolojik tanrılara

7 Bryan R. Wilson, "Aspects of Secularization in the West", Japanese Journal of Religious Studies, Cilt 3, Say1 4, 1976, ss. 259-276.

8 Dobbelaere, ss.112-113.

$9 \quad$ Mark Chaves, "Secularization as Declining Religious Authority", Social Forces, Cilt 72, Say1 3, 1994, ss.758-759. 
ve ritüellere inanmıştır. ${ }^{10}$ Bunların arasında en bilinenleri savaş ve gökyüzü tanrıları Odin ve Thor'dur. Bu inanışı XII. yüzyıla dek devam ettiren İsveç Hristiyanlığa en geç dahil olan İskandinav ülkesidir. ${ }^{11} 829$ y1lında Fransız bir keşiş olan Ansgar'ın dönemin ticaret merkezlerinden olan Birka'ya gelmesi sonrasında Hristiyanlık ile etkileşimin başladığına inanılmaktadır. Bu dönemde Vikingler'in doğu ve batıya yönelik keşifleri de bölgede yaşayan halkın Hristiyanlık ile tanışmasını sağlamıştır. 1008 yılında Götar ve Svear'in kralı Olof Skötkonung ilk kez vaftiz edilen kral; 1210 yilında ise Erik Knutsson bir piskopos tarafindan taç giydirilen ilk kral olmuştur. ${ }^{12}$ Kral ve piskopos özelinde yaşanan bu gelişmeler İsveç'te kilise ile devlet arasında güçlenecek olan bağın da simgesi olmuştur. XII. yüzyılın sonlarında Hristiyanlık İsveç'te giderek yaygınlaşmıştır. Öyle ki Uppsala'da yer alan ve doğrudan Papa'ya bağlı olan başpiskoposluk Katolik Kilisesi'nin önemli merkezlerinden biri haline gelmiş; ülke topraklarının neredeyse beşte birine sahip olan Katolik Kilisesi hasta ve yaşlıların bakımı ve eğitim gibi sosyal yaşama ilişkin konularda aktif olarak faaliyet göstermiştir. ${ }^{13}$

1523 yılında İsveç Kralı olarak taç giyen Gustav Vasa'nın yeni başpiskoposun atanması konusunda Papa ile yaşadığı anlaşmazlık İsveç’te din tarihi açısından önemli bir dönemi başlatacaktır. Martin Luther'in fikirlerinden ve o dönem kıta genelinde baș gösteren reformist hareketlerden etkilenen Olavus ve Laurentius Petri'nin de desteğini alan Kral Vasa Katolik Kilisesi'nden ayrilmayı ve ulusal bir kilise kurmayı planlamıştır. 1531 yllinda Laurentius Petri ilk Evanjelik başpiskopos

10 Sweden-Sverige, "Ten Fundementals of Religion in Sweden", https://sweden.se/society/10-fundamentals-of-religion-in-sweden, (05.12.2017).

11 Sweden-Sverige, "Ten Fundementals of Religion in Sweden", https://sweden.se/society/10-fundamentals-of-religion-in-sweden/, (06.12.2015)

12 Svenska "Kyrkan, "Church History", https://www.svenskakyrkan.se/churchofsweden/church-history, (04.08.2015)

13 Maarit Jantera Jareborg "Religion and the Secular State in Sweden", 18th Annual Congress of the International Academy of Comparative Law, Washington, 25.0701.08.2010, https://www.wcl.american.edu/journal/genderlaw/19/19-1.cfm, (05.08.2015), ss.670-671. 
olarak tayin edilmiş; 1544 yılında ise İsveç Evanjelik krallık olarak ilan edilmiştir. ${ }^{14}$

XVI. yüzyılda İsveç'te “tek hükümdar, tek din” anlayışı hâkim olmuştur. ${ }^{15} \mathrm{Bu}$ dönemde kilise ve toplum arasında dinin ve otoritenin birleştirici unsurlar olduğu bir bütünlük ve yeni bir ulus inşası söz konusudur. 1593 yilındaki Uppsala Toplantısı'nda Evanjelik Lüteryen mezhebin İsveç halkının ulusal dini olarak kabul edilmesi de bu doğrultuda önemli bir adım olmuş ve bu kararın ardından milli bir kilise yani İsveç Kilisesi (The Church of Sweden/Svenska Kyrkan) kurulmuştur. Bu anlayışın hakim olduğu yeni toplumda Uppsala Toplantısı'ndan çıkan kararın yarattığı durum inanç özgürlüğünün olmadiğı; hem ulusal hem de yerel düzeyde devlet ile kilisenin tamamen aynı statüde olduğu; kilisenin dini olmayan görevleri de yerine getirdiği ve din adamlarının aynı zamanda bir kamu personeli gibi çalıştığı bir düzen yaratmıstır. ${ }^{16} \mathrm{Bu}$ dönemde ve ilerleyen y1llarda Kilise'nin aktif bir üyesi olmak ve dini olarak aktif bir yaşam sürdürmek milli bir hissin, vatandaşlı̆̆ın parçası olarak kabul edilmiştir. ${ }^{17}$ XVIII. ve XIX. yüzyıllarda bu sık1 bağın gevşemesi için adımlar atılsa da bu durum uzun süre devam etmiştir.

"Büyük Piskoposlar Dönemi” olarak bilinen XVII. yüzyılda, İsveç'te Kilise ve piskoposlar güçlenmeye başlamıştır. 1634 tarihinde düzenlenen anayasa İsveç'te dini birliğin toplumsal yaşamın ve hukuki düzenin temeli olduğuna; dini olarak bütünleşmiş bir toplumun ülkenin siyasi gücünü arttırmak için gerekli olduğuna hükmetmektedir. Bu hükümler ilerleyen yıllarda da değişiklik yapilmadan yeni anayasalarda korunmuş ancak 1809 yılında kabul edilen anayasada inanç özgürlüğü bağlamında bazı hükümlere yer verilmiștir. ${ }^{18}$ Kilise'nin devlet işlerinde önemli ölçüde etkili olmaya başladığı bu dönemde rahipler ve piskoposlar

14 Svenska Kyrkan, "Church History".

15 Gunnar Edqvist, "Freedom of Religion and New Relations Between Church and State in Sweden", Studia Theologica- Nordic Journal of Theology, Cilt:54, Say1:1, 2000, s.35.

16 Gustafsson, Göran. "Church-State Separation Swedish-style", West European Politics, Cilt: 26, Say1:1, 2003, s.51.

17 Jareborg, s.671.

18 Ibid, s.675. 
yönetimdeki dört kamaradan birini oluşturmuştur. 1686'da yürürlüğe giren kilise kanununda İsveç halkı Evanjelik bir ulus olarak tanımlanmış ve Evanjelik mezhebin öğretilerine göre ibadet etmeleri zorunlu kılınmıştır. Ayrıca kralın Kilise üzerindeki gücü arttırılmış; Evanjelik inanışın gerekliliklerinin toplumsal yaşamda uygulanmasını kontrol eder hale gelmiştir. ${ }^{19}$

XVIII. ve XIX. yüzyıllar bazı dini hareketler ile Kilise yönetimi arasında teolojik farklılıklara dayanan tartıșmalara sahne olmuştur. Bu nedenle bazı gruplar, yasaklara rağmen, İsveç Kilisesi'nden ayrılarak "Özgür Kiliseleri (Free Churches)" kurmuştur. ${ }^{20} 1726$ yllında Kilise dişında herhangi bir dini toplanmanın yasak olduğu ilan edilmiştir. ${ }^{21} \mathrm{Bu}$ dönemde Katolik mezhebine dönüş sürgün ile cezalandırılmış ve bu karar 1858 yılına kadar uygulanmıştır. ${ }^{22}$ Dini alana hâkim olan bu katı tutum 1850'lerden itibaren değişmeye başlamıştır. 1858 yllında bir rahip bulunmadan dua etme hakkı tanınmış; 1860 yllında Roma Katolik Kilisesi'nin ve Metodist-Episcopal Kilise'nin varlı̆̆1 resmi olarak tanınmıştır. 1863 yılında ise herkesin yılda en az bir kez dini toplantılara katılması zorunluluğu kaldırılmıştır. ${ }^{23} 1873$ yılında yalnızca başka bir mezhebe geçme koşuluyla İsveç Kilisesi'nden ayrılma hakkı verilmiştir. Herhangi bir dini topluluğa üye olmaksızın Kilise'den ayrılma hakk1 ise ancak 1951 y1lındaki İnanç Özgürlüğü Kanunu (SFS 1951:680) ile mümkün olmuştur. ${ }^{24}$ Yine de bu dönemde bireylerin herhangi bir inanış1 kabul etmeme veya dini pratiklere dahil olmama hakkı söz konusu değildir.

1862 y1lında İsveç’te yapılan idari düzenleme Kilise ile devlet arasındaki ilişkiye yeni bir boyut kazandırmıştır. İdari yapılanmada gerçekleştirilen reform ile dini işlerde Kilise'nin yerel birimleri (parish);

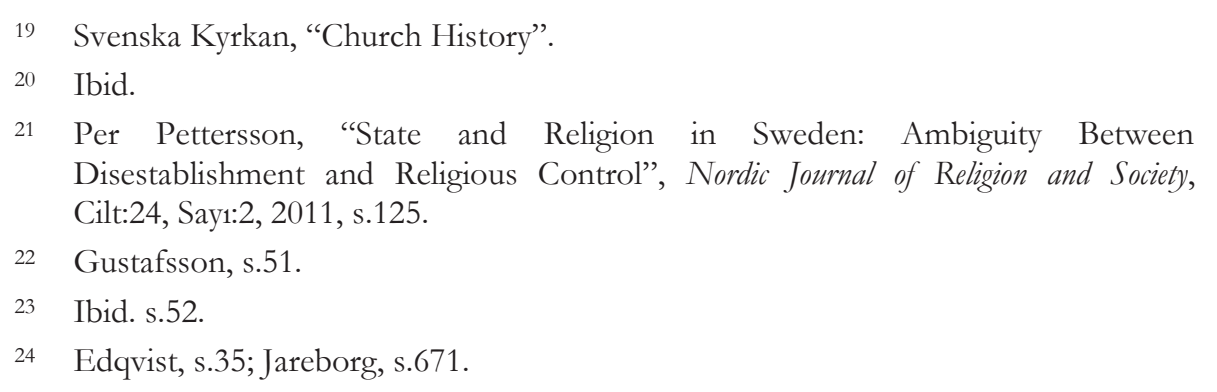


kamusal işlerde ise yerel idari otoriteler sorumlu k1lınmıştır. ${ }^{25}$ Düzenleme ile dini alan ve kamusal alan büyük oranda ayrılmıştır. Kilise'nin devlet yönetimindeki etkisi Meclis'in (Riksdag) kurulmasıyla daha da azalmıştır. 1921 y1lında dört kamaralı sistem kaldırılıp da yerine halen geçerliliğini koruyan meclis sistemi geldiğinde; din adamlarının devlet yönetimindeki varlığına da son verilmiştir. Bu nedenle Kilise'nin kendi içinde bir meclis oluşturulmuş ve bu meclise dini işlerde danışma rolü ve hatta hükümetin dini alandaki önerilerini veto etme hakkı tanınmıştır. ${ }^{26}$ Kilise Meclisi (The Church Assembly/General Synod/Kyrkomötet) piskoposların da dahil olduğu 30 din adamı ve 30 sivil üyeden oluşan ve başpiskopos tarafindan yönetilen bir yapıda oluşturulmuştur. ${ }^{27}$ Yine bu yıllarda inanç özgürlüğü, eşit muamele, eğitim ve sosyal yaşamda dini otoritenin son bulması yönünde talepler de gündeme gelmiştir. 1908 yllında kabul edilen bir yasayla yurttaşlara Kilise dışında evlilik hakkı tanınmıştır. 1927 yılında ise cenazelere ilişkin yasada yapılan değişiklikle İsveç Kilisesi'nin uygun gördüğü ritüellere göre defnedilme zorunluluğu kalkmıştır. ${ }^{28} 1917$ yılında Liberal Parti ile koalisyon oluşturan Sosyal Demokrat Parti eğitimin yalnızca Lüteryen mezhebin öğretilerine göre yapılamayacağını söyleyerek eğitimi kiliseye ait yerel birimlerin yetki alanından çıkartıp yerel idari otoriteye vermiştir. ${ }^{29}$

Siyasi alanda sekülerleşme adımları devam ederken İsveç Kilisesi de kendini yeniden tanımlamaya çalışmış; bu çabaların neticesinde "halk kilisesi (folkchurch/Folkkeyrkea)" yaklaşımı ortaya çıkmıştır. ${ }^{30}$ Bu yaklaşıma göre Kilise'nin İsveç'teki her vatandaşa, her düzeyde açık olması fikrini benimsenmiştir. Bu yaklaşım özellikle devletin sekülerleşme çabalarına karşılık Kilise'nin toplumsal yaşamdaki etkisini sürdürmeye çalıştı̆̆ını göstermesi bakımından önemlidir. Bu dönemde Kilise'nin kimliğini ve konumunu tanımlama çabalarına Meclis’in Kilise'yi bağımsızlaştırma

\footnotetext{
Edqvist, s.35.

Gustafsson, s.52.

Svenska "Kyrkan, "Church and State", http://www.svenskakyrkan.se/churchofsweden/church-and-state, (04.08.2015). 
çabası eşlik etmiştir. 1930 yılında Meclis tarafından alınan bir kararla Kilise'ye ait yerel birimlerin bazılarında nispi temsile dayalı seçimle bir meclis oluşturulmasına karar verilmiştir. 1932 yılinda yine Meclis tarafindan alınan bir kararla bu birimlerin bulundukları bölgede İsveç Kilisesi'nin yüzyıllardır sahip oldukları mülklerden elde edilen geliri kullanabileceklerine hükmedilmiştir. Bu durum kiliseye bağl1 birimlerin önemli bir mali kaynağa erişmeleri ve bu kaynağı kullanmalarında serbestlik vermiştir.

1956 y1linda bazı Meclis üyeleri Kilise ile devletin muhtemel ayrıllğına ve böyle bir kararın nasıl etkileri olacağına dair araştırma yapılmasını talep etmiştir. Hükümetin de önerisiyle 1958 yılında kurulan "Kilise ve Devlet Komisyonu (Church-State Comission)" on y1l boyunca çalışmış ve 1968 tarihli raporunda dört farklı model önermiştir:

- 1. Model: Kilise ile devlet arasındaki ilişkide radikal bir değişiklik öngörmemiştir.

- 2. Model: Kilise'nin devletten tamamen ayrilmasinı ancak Kilise'ye ait mülklerin yine Kilise'de kalmasını ve Kilise'nin üyelerinden toplayacağ1 vergi benzeri bir aidatın toplanması konusunda devlet yardımını öngörmüştür.

- 3. Model: B modeli ile aynı öneride bulunulmuş ancak vergilerin toplanmasında devlet yardımı öngörülmemiştir.

- 4. Model: Devlet ile Kilise'nin tamamen ayrilmasinı ve Kilise binaları dışındaki tüm mülkün kamulaştırılmasını öngörmüştür. ${ }^{31}$

Rapor zamanın dini işlerden sorumlu bakanı Olof Palme'ye iletilmiş; bunun üzerine Meclis düzeyinde yeni bir araştırma komisyonu kurulmuştur. Komisyon, 1972 tarihli raporunda Kilise ve devlet arasındaki müzakerelerin temelinin inanç özgürlüğü olmas1 gerektiğini belirmiştir. Komisyon'a göre, herhangi bir vatandaş, ülkenin neresinde yaşarsa yaşasın, tek bir inanışı benimsemek zorunda kalmamalı; aksine her türlü inancin ifade ve ibadet özgürlügünü sunan bir toplum içinde kendi dinsel tatmini yaşayabilmeli; tüm dini toplulukların eşit muamele

31 Ibid. s.57. 
görmelidir. Komisyon için inanç özgürlüğün diğer bir gerekliliği genel kamusal hizmetlerin İsveç Kilisesi'nden sivil otoritelere geçmesidir. Bu nedenle İsveç Kilisesi içişlerini ilgilendiren hususlarda özerk olmall; Kilise'nin vatandaşları vergilendirme yetkisinin sona ermeli ve devlet tarafindan dini topluluklara mali yardım sağlamak üzere yeni bir sistem geliştirilmelidir. $^{32} 1983$ yllında Kilise'nin resmi devlet kilisesi statüsüne son verileceğini öngören rapora kamuoyundan, Kilise'den ve Meclis'ten güçlü itirazlar gelmiştir. ${ }^{33}$

1980-1990 yılları arasında yapılan değişiklikler ileride yapılacak olan reform için zemin hazırlamıştır. Bu dönemde Kilise'nin yapısı kamusal yapıdan hükümet dışı bir organizasyona doğru kaymıştır. 1983 yılında Kilise Meclisi güçlendirilmiş; 1989 yılındaki idari yapıya yönelik değişiklikler yapılmıştır. Örneğin, Kilise'nin artık yalnızca dini bir kuruluş olması nedeniyle vergi kaydının yalnızca devlete bağlı vergi otoritelerince yapılmasına karar verilmiştir. ${ }^{34}$

1988 yllinda Kilise Meclisi, hükümetten muhtemel reformlar sonrasında Kilise'nin yasal ve mali durumunu netleştirmek maksadıyla bir araştırma yapmasını talep etmiştir. 1992 yılında ortaya konulan raporda üç farklı model önerilmiştir. İlk model mevcut düzende Kilise'ye daha fazla bağımsızlık verilmesini öngörmekte; ikinci model Kilise'ye oldukça geniş bir serbestlik sunulmasını ancak Kilise'yi yasal kontrol altında tutmayı öngörmektedir. Üçüncü modelde ise Kilise'nin diğer dini topluluklar ile aynı statüde yer alması; aynı yasal ve mali uygulamalara tabi olması önerilmiştir. Her üç modelde de Kilise'nin o güne dek sahip olduğu mülkler yine Kilise'ye ait olmaya devam edecektir. ${ }^{35}$

1994 y1linda sunulan başka bir rapor 1968 ve 1972 tarihli raporların temel yaklaşımına benzese de bu raporda sunulan öneri hem İsveç Kilisesi'ni hem de diğer dini toplulukları kapsamıştır. Raporda yer alan anahatlar doğrultusunda 1995 yllının sonuna doğru Meclis'e sunulan tasarıly dini toplulukların statüsüne ilişkin uzun vadeli ve anayasal düzeyde bir çözüm bulunması; dini toplulukların resmi biçimde

\footnotetext{
32 Edqvist, s.36.

Gustafsson, s.58.

Ibid., s.122.

35 Gustafsson, s.65.
} 
tanınmasını sağlayacak bir süreç oluşturulması ve İsveç Kilisesi'nin genel kamu hizmetlerine ilişkin yürütmekte olduğu görev ve sorumlulukların yeniden düzenlemesi hedeflenmiştir. ${ }^{36}$ Tasarı Kilise Meclisi'nde ve İsveç Meclisi'nde oy çokluğu ile kabul edilmiştir.

1 Ocak 1996'da İsveç Kilisesi'ne üye olma koşulu değiştirilmiş ve üyeliğin doğumla değil vaftiz ile başlayacağına karar verilmiştir. Bir anlamda yeni yasa ile Kilise üyeliğinin kendiliğinden olması değil isteğe bağlı olarak yapılması sağlanmıştır. 1998 yılında ise Meclis, yasal mevzuatta değişiklik yaparak Kilise ve devletin ayrılması ve diğer dini toplulukların resmi olarak tanınması yönünde karar almış; İsveç Kilisesi Kanunu (SFS 1998:1591) ile Dini Topluluklar Kanunu (SFS 1998:1593) çıkarılmıştır. Bu gelişmelerin sonucunda Kilise Meclisi 1999 yılında çıkardığı kararname ile (Ordinance of Church of Sweden) Kilise'nin iç işlerini ilgilendiren yasal mevzuatın büyük bir kısmını kendi iç düzenlemelerine dahil etmiştir. ${ }^{37}$ Kilise ve devlet tarafindan paralel biçimde gerçekleştirilen bu reformlar 1 Ocak 2000 tarihi itibarıly uygulanmaya başlanmıştır.

\section{Yasal Düzenlemeler Işığında İlişkilerin Bugünü}

İsveç'te tek bir anayasa yerine dört farklı belge mevcuttur ve bu belgeler anayasa niteliğindedir. ${ }^{38}$ Kilise ve diğer dini toplulukların statüsünü ve devletle olan ilişkilerini düzenleyen özel kanunların yanı sıra anayasal nitelikteki belgelerde de devletin inanç özgürlügüne yaklaşımına dair genel hükümler mevcuttur.

Dört temel belgeden biri olan Instrument of Government ${ }^{39}$ kamu kurumlarının her türlü ayrımcılıkla mücadele edeceğine hükmetmekte;

\footnotetext{
Ibid, ss.65-66.

37 Pettersson, s.123.

381974 tarihli Instrument of Government, 1810 tarihli Veraset Kanunu (Act of Succession), 1949 tarihli Basın Özgürlüğü Kanunu (Freedom of the Press Act), 1991 tarihli İfade Özgürlüğü Kanunu (Fundemental Law on Freedom of Expression).

39 Belge İsveç'te anayasa yerine geçen dört belgeden biri olup Türkçe'de doğrudan bir karşılı̆̆ının bulunmaması nedeniyle İngilizce olarak kullanılmıştır. Bknz: Sveriges Riksdag, "The Instrument of Government", http:/ /www.riksdagen.se/Global/dokument/dokument/laws/The-Instrument-ofGovernment-2015.pdf, (19.11.2015).
} 
buna inanç temelli ayrımcllı̆̆1 da dahil etmektedir (Bölüm 1 Madde 2). Aynı belge vatandaşların tek başına ya da topluluk halinde ibadetlerini ifa edebileceğini (Bölüm 2 Madde 1) ve vatandaşların dini görüşlerini açıklamaya zorlanamayacağını bildirmektedir (Bölüm 2 Madde 2).

Yazılı basın özgürlüğüne ilişkin hükümlerin yer aldığ1 1949 tarihli Basın Özgürlüğü Kanunu ${ }^{40}$ (Freedom of the Press Act)'na göre bir kişi veya gruba inanç, $1 \mathrm{rk}$, etnik köken, cinsel yönelim gibi unsurlar üzerinden herhangi bir ima, kınama ya da tehditte bulunulması mevcut yasal düzenlenmeler doğrultusunda suç olarak kabul edilmektedir (Bölüm 7 Madde 4).

Anayasal metinlerle garanti altına alınan inanç özgürlüğünün istisnas1, 1810 tarihli Veraset Kanunu (Act of Succession)'na ${ }^{41}$ göre kralın veya kraliçenin Evanjelik mezhebinden olması koşuludur (Madde 4). Buna göre, kral veya kraliçe başka bir dine veya mezhebe geçmek isterse bu görevinden istifa etmelidir. Aynı kanuna göre prens ve prensesler de Evanjelik inanışa göre yetiştirilmelidir (Madde 5).

Anayasal belgelerin yanı sıra 1950 tarihli İnsan Hakları ve Temel Özgürlüklerin Korunmasına İlişkin Sözleşme, 1994 yıllnnda İsveç hukukuna entegre edilmiş ve Sözleşme'de tanınan hak ve özgürlükler anayasal olarak teminat altına alınmıştır. Bu nedenle İsveç halkı hem anayasa hem de uluslararası sözleşmeden gelen bir koruma altındadır. ${ }^{42}$

Instrument of Government a göre İsveç Kilisesi ve dini topluluklara ilişskin düzenlemeler kanunlar aracılı̆̆ıyla yapılmaktadır (Bölüm 8 Madde 2). Kilise'yi ve dini toplulukları düzenleyen kanunların değiştirilmesi veya yürürlükten kaldırılması Meclis’te nitelikli oy çokluğu ile alınacak kararla

\footnotetext{
40 Sveriges Riksdag, "The Freedom of the Press Act", https://www.riksdagen.se/Global/dokument/dokument/laws/The-Freedom-ofthe-Press-Act-2015.pdf, (19.11.2015).

41 Sveriges "The Act of Succession", https://www.riksdagen.se/Global/dokument/dokument/laws/the-act-ofsuccession-2012.pdf, (19.11.2015).

42 Jareborg, s.676.
} 
mümkündür. ${ }^{43}$ Mevcut durumda bu düzenlemeleri ele alan kanunlar şunlardır:

1. İsveç Kilisesi Kanunu ${ }^{44}$ (Act on the Church of Sweden) (SFS 1998:1591) ${ }^{45}$ : 26 Kasım 1998 tarihinde yayınlanan ve 1 Ocak 2000 tarihinde yürürlüğe giren kanun daha önce var olan Kilise Kanunu (Ecclesiastical Act)'nun yerine geçmiştir. Kanun İsveç Kilisesi'nin statüsü, idari yapıs1, Kilise'ye ait mülk ve gelirler ile Kilise'ye ait belgeler ve bu belgelere erişim hakkını düzenlemektedir.

2. Dini Topluluklar Kanunu (Act on Religious Communities) (SFS 1998:1593) ${ }^{46}: 26$ Kasım 1998 tarihinde yayınlanan kanunun 1 Ocak 2000 tarihinde yürürlüğe girmesi ile İnanç Özgürlüğü Kanunu (1951:680) lağvedilmiştir. Kanunun genel hükümlerinde Insan Hakları ve Temel Özgürlüklerin Korunmasına İlişkin Sözleşme’ye atıf yapılmaktadır. İsveç Kilisesi dışındaki dini toplulukların statüsü, kayıt koşulları, üçüncü taraflarla ilişkileri ve bu topluluklara devlet yardımı bu kanunda düzenlenmektedir.

3. Dini Toplulukların Kaydına İlişkin Kararname (Ordinance on Registration of Religious Communities) (SFS 1999:73147: 26 Ağustos 1999 tarihinde yayınlanan; 1 Ekim 1999 ve 1 Ocak 2000 tarihlerinde çeşitli maddeleri yürürlüğe giren kanun ile İsveç Kilisesi dışındaki dini toplulukların kayıt altına alınmasına ilişkin süreç düzenlenmektedir.

43 Ministry of Culture-Sweden, "Changed Relations between the State and the Church of Sweden", http://www.sst.a.se/download/18.4c1b31c91325af4dad3800015546/13771884287 60/Fact+sheet+about+state-church+relations.pdf, (04.08.2015).

44 Metnin devamında "İsveç Kilisesi Kanunu" ile "Kilise Kanunu” birbirinin yerine kullanılmıştır.

45 SST, "Act on Church of Sweden", http:/ /www.sst.a.se/download/18.4c1b31c91325af4dad3800015541/13771884289 04/Act+on+Church+of+Sweden+Act.pdf, (04.08.2015).

46 SST, "Act on Religious Communities Signatures", http:/ / www.sst.a.se/download/18.4c1b31c91325af4dad3800015529/13771884288 75/Act+on+religious + communities.pdf, (04.08.2015

47 SST, "Ordinance on Registration of Religious Communities", http:/ /www.sst.a.se/download/18.4c1b31c91325af4dad3800015537/13771884288 21/Ordinance+on+Registration+of+Religions+Communities.pdf, (04.08.2015). 
4. Dini Topluluklara Destek Kanunu (Act on Support to Religious Communities) (SFS 1999:932) ${ }^{48}: 25$ Kasım 1999 tarihinde yayınlanan ve 1 Ocak 2000 tarihinde yürürlüğe giren kanun dini topluluklara devlet tarafından sağlanacak desteklerin kapsamı ve koşulları ile bu desteğin verilmesine aracılık eden kurumların bu alana ilişkin sorumluluklarını düzenlemektedir.

5. Kayıtlı Dini Topluluklar için Aidat Kanunu (Act on Fees to Registered Religious Communities) (SFS 1999:291) ${ }^{49}$ : Dini toplulukların üyelerinden alınacak aidatn hesaplanması, toplanması ve yönetilmesinde devlet tarafindan sağlanacak desteğe ilişkin düzenlemeler içeren kanun 1 Ekim 1999 y1lında yürürlüğe girmiş ve müteakip vergi yllı olan 2000 yilında uygulanmıştır.

Dini Topluluklar Kanunu'na göre hiç kimse bir dini topluluğa bağlı olmak zorunda değildir. Bunun aksini bildiren herhangi bir anlaşma yahut sözleşme geçersiz kabul edilmektedir (Madde 3). Kanunda ayrıca 12 ve üzeri yaştaki çocukların kendi rızaları olmadan bir dini topluluğa üye yapılamayacağ1 yahut üyelikten çıkartılamayacağ1 ifade edilmektedir (Madde 4).

Yukarıda bahsi geçen diğer kanunların İsveç Kilisesi, dini topluluklar ve devletin dini meselelere olan yaklaşımlarına aşağıdaki alt başliklarda yer verilmiştir.

\subsection{Kilisenin Konumuna İlişkin Düzenlemeler}

Nüfusu 10 milyona yaklaşan İsveç’te 2011 yllı verilerine göre halkın \%57,5’i İsveç Kilisesi'ne bağlıdır. ${ }^{50} \mathrm{Bu}$ özelliği ile kilise 2000 y1lındaki reformla birlikte devlet kilisesi olmaktan çıssa da hala ulusal kilise olarak tanımlanmaktadır ve bu durum Kilise Kanunu'nun 2nci maddesinde hüküm altına alınmıştır. Kanun'un 1'inci maddesine göre

\footnotetext{
48 SST, "Act on Support to Religious Communities", http:/ /www.sst.a.se/download/18.4c1b31c91325af4dad3800015531/13771884288 50/Act+on+support+to+religious+communities.pdf, (04.08.2015).

49 SST, “Act on Fees to Registered Religious Communities", http:/ /www.sst.a.se/download/18.4c1b31c91325af4dad3800015535/13771884288 90/Act+on+Fees+to+Registered+Religious+Communities.pdf, (04.08.2015).

50 World Values Survey, s.16.
} 
Evanjelik Lüteryen bir kilise olan İsveç Kilisesi'nin sekretaryası Orta Çağ'dan bu yana Uppsala kentinde yer almaktadır. Yerel ve bölgesel düzeyde örgütlenmiş olan Kilise'ye ait ülke genelinde 3500 kilise ve 13 piskoposluk bölgesi bulunmaktadır. ${ }^{51}$

Kilise Kanunu'na göre Kilise'ye bağlı yerel birimler bulundukları bölgelerde dini hizmetlerin yanı sıra toplumsal refahı sağlamak üzere hizmetler sunmaktadır (Madde 4). Nitekim günümüzde İsveç Kilisesi’ne bağlı yerel örgütlenmeler dini faaliyetlerin yanı sıra sosyal hizmet niteliğindeki faaliyetlerde de bulunmaktadır. Örneğin hastalara, yaşlılara veya bağımlı kişilere danışmanlık vermek, çeşitli meslek kursları tertip etmek, bazı durumlarda ise kadınlar başta olmak üzere ihtiyaç duyan gruplara finansal destek sağlamak bu faaliyetler arasındadır. Bazı bölgelerde Kilise'nin kurduğu veya yönetiminde rol aldığ1 yaşlı bakım evleri, sağlık kuruluşları ve gençlik merkezlerinin olması Kilise'nin bu rolünü kısmen kamusal alanda da görmemize neden olmaktadır. ${ }^{52}$ Bölgeler piskoposlar tarafindan yönetilmekte olup yerel birimlerin sunduğu hizmetlerin kontrol edilmesi ve geliştirilmesinden sorumludurlar (Madde 5). Kanunda Kilise'nin ulusal düzeyde faaliyet gösteren, herkese açık ve demokratik bir yapıya sahip olduğu ifade edilmektedir. Kilise ulusal düzeyde Uppsala Başpiskoposu tarafindan yönetilmekte; uluslararası düzeyde de aynı makam ile temsil edilmektedir (Madde 2).

Karar alma mekanizmaları, din adamlarının atanması, mali yönetimi gibi Kilise'nin işleyişine ilişkin alanlar ise 1999 tarihli bir kararname ile düzenlenmektedir. Piskoposlar yaşam boyu bu görevde kalmak üzere tayin edilmekte ancak en geç 67 yaşında emekli olmaları beklenmektedir. Papazlar ise yerel birimler veya piskoposlar tarafindan

51 Svenska Kyrkan, "Welcome to the Church of Sweden", https://www.svenskakyrkan.se/english, (04.08.2015).

52 İsveç Kilisesi'nin yereldeki hizmetleriyle refah devleti uygulamalarına nasıl katkı sağladığına ilişkin Gävle bölgesindeki uygulamalar üzerinden yapılan detaylı bir analiz için bknz. Ninna Edgardh Beckman, Thomas Ekstrand, Per Pettersson, "The Church of Sweden as an Agent of Welfare - the case of Gävle", Churches in Europe as Agents of Welfare - Sweden, Norway and Finland (ed. Anne Birgitta Yeung), SLU Repro, Uppsala, 2006, ss.20-85. 
İsveç İş Kanunu'nda belirtilen prosedürlere göre, nitelikleri doğrultusunda ve mülakat neticesinde işe alınmaktadır. ${ }^{53}$

Kilise-devlet ilişkisindeki reformlar tarihsel süreç içinde incelendiğinde en önemli amaçlardan birinin Kilise'nin iç işlerinde karar alma mekanizmasindan devleti çıkartmak ve bunu tamamen Kilise'nin kontrolüne vermek olduğu anlaşılmaktadır. Bu amaçla 1 Ocak 2000'den bu yana piskoposlar hükümet tarafindan atanmamakta; Kilise üyeleri ve din adamlarının birlikte karar verdiği bir sistemle seçilmektedir. ${ }^{54}$ Buna göre, her dört yılda bir İsveç Kilisesi'nde ulusal, bölgesel (piskoposluk bölgesi) ve yerel düzeyde seçim yapılmakta; bölgelerden sorumlu piskoposlar bölgedeki papazlar ve aynı sayıdaki sivil üye tarafından seçilmektedir. Kilise Kanunu'nun 6'ncı maddesinde Kilise'nin en yüksek düzeyde karar alma organı Kilise Meclisi olarak belirtilmiştir. 251 üyeden oluşan Kilise Meclisi yılda iki kez toplanmakta ve Kilise'nin iç işlerine dair kararlar almaktadır. ${ }^{55}$

Kilise Kanunu'na göre Kilise üyeleri yerel ve bölgesel vergi ödemek zorundadır. Yerel vergi yerel birimler tarafından, bölgesel vergi ise piskoposluklar tarafindan belirlenmektedir. Kiliseye bağlı mülklerden ve din adamlarının maaşları için kullanılan yatırımlardan elde edilen gelirler Kilise'nin temel mali kaynağını oluşturmaktadır (Madde 7 ve Madde 8).

Reform sonrasında da İsveç Kilisesi -yerel birimleri aracilığıylacenaze ve defin hizmetleri için temel sorumlu olmaya devam etmektedir. Bu amaçla, Dini Topluluklara Destek Kanunu'nda da belirtildiği üzere, Kilise üyelerinin ödeyeceği aidata cenaze ve defin işlemleri için de belirli miktar eklenmektedir (Madde 2). Bununla birlikte, herhangi bir dine mensup olmayan veya dini ritüller eşliğinde defnedilmeyecek kişiler için

\footnotetext{
53 Svenska Kyrkan, "Ministry and Ministries", https://www.svenskakyrkan.se/churchofsweden/ministry-and-ministries, (04.08.2015).

54 Pettersson, s.123.

55 Svenska Kyrkan, "Welcome to the Church of Sweden".
} 
İsveç Kilisesi dini sembollerden arınmış bir defin alanı sunmakla yükümlüdür. ${ }^{56}$

Kilisenin 36 milyar SEK değerinde varlığı olduğu; y1llık 19 milyar SEK civarında ise maliyetinin olduğu tahmin edilmektedir. Harcamalarında ve faaliyetlerinde hesap verebilirlik ve şeffaflık sağlamak adına Kilise bunlara ilişkin bilgileri yıllık raporlarında yayınlar ve bu bilgiler kamuoyu tarafindan incelenebilmektedir. ${ }^{57}$ Kayıtlı Dini Topluluklar için Aidat Kanunu'na göre Kilise üyelerinin verdikleri aidata, Cenaze Yasas1 (Funeral Act, SFS 1990:1144)'na uygun olarak, cenaze masrafları için de aidat eklenmektedir. Ancak Kilise yerine yerel idari otoritenin cenaze ve defin işlemleri için temel sorumlu ve yetkili olduğu bölgelerde yaşayanlar için bu geçerli değildir (Madde 2).

2002 yılı itibarıyla İsveç Kilisesi kültürel mirasını korumak için devletten destek almaktadir. Devlet ile Kilise arasında Kilise'nin malvarllğ1 ve kültürel değerlerinin korunmasına ilişkin uzun süreli bir anlaşma söz konusudur ve yalnızca 2002-2009 y1lları arasında toplam 1,9 milyar SEK bu amaçla ayrılmıştır. ${ }^{58}$

\subsection{Diğer Dini Toplulukların Statüsü}

Dünya Değerler Araştırması (World Values Survey-WVS)'na göre 2011 yılı itibarılla İsveç halkının \%2,4’ü Özgür Kiliseler'e bağlıdır. İsveç Kilisesi'nin dışında en etkili kiliseler olan Özgür Kiliseler genel olarak Metodist, Pentecostal ve Baptist mezheplerden oluşmaktadır. Smaland şehrinde bulunan Jönköping çevresi bir hayli yoğun olan Özgür Kilise aktivitelerinden ötürü İsveç İncil Şeridi olarak anılmaktadır. ${ }^{59}$ İsveç Kilisesi ve Özgür Kiliseler dışında, İsveç’te halkın bağlı olduğu inançlar oldukça çeşitlidir. WVS’ye göre İsveç nüfusunun \%2,4’ü Müslüman;

56 Ministry of Culture-Sweden, "Changed Relations between the State and the Church of Sweden".

57 Sweden-Sverige, "Ten Fundementals of Religion in Sweden".

58 Ministry of Culture-Sweden, "Changed Relations between the State and the Church of Sweden".

59 Sweden-Sverige, "Ten Fundementals of Religion in Sweden". 
$\% 1,3$ 'ü Katolik; \%0,8', Ortodoks; \%0,2'si Hindu; \%0,1'i Budist ve \%0,1’i Yahudi'dir. ${ }^{60}$

\subsubsection{Yasal Statü}

Dini topluluklara ilişkin konular 1998 tarihli Dini Topluluklar Kanunu ile düzenlenmektedir. Kanun'un ilk maddesi inanç özgürlüğünü vurgulamakta ve Instrument of Government ile İnsan Haklar1 ve Temel Özgürlüklerin Korunmasına İlişkin Sözleşme'de yer alan maddelere atıf yapmaktadır. Kayıtlı dini topluluklar İsveç Kilisesi ve bu yasaya göre kayıt altına alınmış topluluklardan oluşmaktadır. Mevcut durumda İsveç'te kayıtlı olan 42 dini topluluk bulunmaktadır. Bunlardan altısı Özgür Kiliseler; on yedisi Ortodoks ve Doğu Ortodoks Kilisesi (Ermeni Kilisesi, Bulgar Ortodoks Kilisesi, Sirp Ortodoks Kilisesi, Suriye Ortodoks Kilisesi İsveç Başpiskoposluğu vd.); sekizi Evanjelik Lüteryen Kilise (Danimarka, Estonya, Macaristan, Norveç Evanjelik Lüteryen Kiliseleri vd.); altısı Müslüman cemaatleridir (İsveç Müslümanları Federasyonu, İsveç İslami Kültür Merkezleri Birliği, İsveç İslam Dernekleri Federasyonu, İsveç Şii Müslümanlar Birliği vd.). Bunların dışında diğer Hristiyan kiliseler olan İsveç Anglikan Kilisesi ve Stockholm Katolik Piskoposluğu ile İsveç Yahudi Cemaati, İsveç Budist Birliği ve Mandean Sabiilik Cemaati de kayıtlı dini topluluklar arasindadir. ${ }^{61}$

Dini Toplulukların Kaydına İlişkin Kararname'ye göre toplulukların kaydından Yasal, Mali ve Yönetim Hizmetleri Ajansı (Legal, Financial and Administrative Services Agency) sorumludur (Madde 2). Bir dini topluluğun kayıt olabilmesi için topluluğun kuruluş amacı ve karar alma mekanizmasını açıkça anlatan bir tüzüğe ve bir yürütme kuruluna veya bu nitelikte bir organa sahip olması gerekmektedir. Ayrıca topluluğun faaliyetlerine uygun ve diğer dini topluluklardan ayırt edilecek nitelikte bir isme sahip olması gerekmektedir. Bu koşullara haiz olan dini topluluklar kayıt altına alınmakta ve bir kayıt numarasına sahip olmaktadır (Madde 4). Kayıt işlemi topluluğun kendisi ve tüm bağlı örgütlenmeleri için

\footnotetext{
World Values Survey, s.16.

${ }^{61}$ Detaylı liste için bknz: SST, "SST in English", http:/ /www.sst.a.se/inenglish.4.7f968fc211eeec933de800011945.html
} 
yapılmaktadır. 2015 yılı itibarıyla kayıt için her bir topluluktan y1llık 500 SEK ücret alınmaktadır. ${ }^{62}$

\subsubsection{Finansal Destek}

Dini Topluluklar Yasası'na göre dini topluluklar üyelerinden aidat toplanması, bu aidatların hesaplanması ve yönetilmesinde devletten destek alabilmektedir. Ancak bu desteği almanın koşulları topluluğun faaliyetleri araciliğıyla toplumun temel değerlerinin korumasi ve güçlendirmesine katkı sağlaması, topluluğun kendi kaynaklarıyla ve aktif olarak faaliyet gösterebilmesidir (Madde 16). Kayıtlı Dini Topluluklar için Aidat Kanunu'na göre üyelerden toplanan aidatlar vatandaşların vergiye tabi gelirleri üzerinden ve yerel vergi oranlarına göre hesaplanmakta; aidatların hesaplanmasında ve diğer ilgili işlemlerde Vergi Yasası (Tax Payment Act, SFS 1997:483) hükümleri gözetilmektedir (Madde 3 ve Madde 4). Aynı kanun gereği İsveç Kilisesi dışındaki dini topluluklar aidatların toplanması için destek almadan önce üyelerinden aidat toplanmasına ilişkin yazılı izin almak zorundadır (Madde 6). Bu amaçla devlet desteğini alan toplulukların üyelerinden alınan aidatlar vergi sisteminin bir parçası olduğundan, aidatların zamanında ödenmemesi halinde devlet yetkilileri tarafindan tahsil edilmekte; ödenmemesi halinde ise üyenin maaşına veya mallarına haciz konulabilmektedir. ${ }^{63}$

Dini topluluklara sağlanan destek hibe şeklinde de olabilir ve hibeler toplulukların eğitim, bakım, dini hizmetler gibi dini nitelikteki faaliyetlerini uzun vadede sürdürebilmeleri içindir. Kayıt altına alınmış olan dini topluluklara, Dini Topluluklara Destek Kanunu doğrultusunda, İsveç İnanç Topluluklarına Kamu Desteği Komisyon ${ }^{64}$ (Swedish

62 Kam Markollegiet, "Registration of Religious Communities", http://www.kammarkollegiet.se/english/registration-religious-communities, (06.12.2015).

63 Lars Friedner, "İsveç, Din Devlet İlişkisi: Hukuki Yap1, Dini Kurumlar, Din Eğitimi ve Din Hizmetleri”, AB Ülkelerinde Din-Devlet İliskisi Sempozyumu Kitabr, İslam Araştırmaları Merkezi, İstanbul, 09-10.12.2006, s.479.

64 İngilizce kaynaklarda kullanılan "religious communities" kavramı bu metinde "dini topluluklar" şeklinde çevrilmiştir. "Swedish Commission for Government Support to Faith Communities" örneğinde olduğu gibi "faith" ve "belief" kelimeleri ise "inanç" olarak tercüme edilmiştir. 
Commission for Government Support to Faith Communities/Nämnden för statligt stöd till trossamfund) tarafindan devlet desteği aktarılmaktadır. Komisyon üyeleri dini topluluklardan gelen tekliflerin değerlendirilmesi neticesinde hükümet tarafindan atanmaktadır. ${ }^{65}$ Komisyon aynı zamanda dini topluluklar arasındaki iş birliği ve diyaloğun artmasını teşvik etmekte; afet gibi acil durumlarda bu toplulukların faaliyetlerinin organize edilmesini sağlamaktadır. Komisyon aracılığıyla verilen destekler üçe ayrılmaktadır:

- Organizasyonel hibeler

- Çalışmalara sağlanan hibeler (kurumlarda sağlanan dini hizmetler)

- Proje bazlı hibeler ${ }^{66}$

Üyelerinden üyelik aidatı toplamak için devlet desteğinden yararlanan dini topluluklara doğrudan devlet desteği yan hibe daha az miktarda verilmektedir. ${ }^{67} \mathrm{Bu}$ şekilde sağlanan desteklerden İsveç Kilisesi yararlanamamaktadir. ${ }^{68}$

\subsubsection{Din Dersleri}

İsveç'teki kamu okulları mezhepler üstü bir yapıda olmakla birlikte din dersi de diğer alanlar gibi zorunlu eğitim içinde yer almaktadır ve derste devlet tarafindan belirlenen müfredat takip edilmektedir. Öğretmenler rahip, imam gibi din adamlarını kendi dinlerini /mezheplerini tanıtmak için derse davet edebilirler. ${ }^{69}$ WVS'nin sonuçları incelendiğinde bu durumun İsveç halkının beklentileri ile örtüştüğü anlaşılmaktadır. Zira 2011 yllı verilerine göre tüm inançların kamu okullarında öğretilmesi gerektiğine inanların oranı \% $\% 5,3^{\prime}$ tür. $^{70}$

65 Friedner, "İsveç, Din Devlet İlişkisi: Hukuki Yapı, Dini Kurumlar, Din Eğitimi ve Din Hizmetleri”, s.475.

66 SST, "SST in English".

67 Friedner, “İsveç, Din Devlet İlişkisi: Hukuki Yap1, Dini Kurumlar, Din Eğitimi ve Din Hizmetleri", s.475.

68 SST, "SST in English".

69 Friedner, "İsveç, Din Devlet İlişkisi: Hukuki Yap1, Dini Kurumlar, Din Eğitimi ve Din Hizmetleri", ss.473-474.

70 World Values Survey, s.18. 
İsveç’te dini eğitim veren özel okullar da açllabilmektedir. Mezhepsel (confessional) eğitimin yoğun olduğu bu okullarda dini semboller kullanılabilir; eğitim dahilinde ibadet saatlerine yer verilebilir. Ancak bu okullarda dahi öğrencilerin dini eğitime veya ibadet saatlerine katılımı gönüllüğe bağlıdır; dayatılamaz. ${ }^{71}$ Okullarda dini sembollerin kullanılması ve giyim şekline ilişkin düzenleme ise 2003 y1lında Ulusal Eğitim Ajansı (The National Agency for Education/Skolverket) tarafindan verilen karar doğrultusunda okul yönetimine bırakılmıştır. ${ }^{72} \mathrm{Bu}$ okulların açılması Ulusal Eğitim Ajansı’nın iznine bağlı olup din derslerinin dışında ulusal eğitimin genel amaçları ve kriterleri ile uyumlu bir müfredata sahip olması gerekmektedir. Diğer bir koşul da bu okulların mezhep gözetmeksizin tüm çocuklara açı olması ve öğretmenlerinin ilgili kanunda yer alan genel nitelikleri karşılamasıdır. ${ }^{73} 2008$ yılı verilerine göre İsveç’te devlet tarafindan yetkilendirilen ve kamusal mekanizmalarla desteklenen bu tarz okullar İsveç'teki okulların \%10'unu oluşturmaktadır. ${ }^{74}$ Mezhebe dayalı eğitim veren özel okulların varlı̆̆ının toplumsal düzeyde bir ikileme sebep olduğunu düşünenler de vardır. Bu okullarda verilen eğitimin bireylerin dinsel pratiklerini öğrenmeleri ve sürdürmelerine olanak sağlamakla birlikte bazı azınlık grupların kendi kültürel alanlarında sıkışmasına ve ayrışmasına neden olabileceğinden endişe edenler vardır. ${ }^{75}$

Ülkede din adamlarının eğitimi bağlı bulundukları dini topluluğun düzenlemesine tabidir. ${ }^{76}$ İsveç Kilisesi'ne bağlı din adamları temel olarak Uppsala ve Lund Üniversiteleri'nde eğitim görmektedir. ${ }^{77}$ İsveç'teki dinsel çeşitlilik dini eğitim konusunda da yenilik arayışını getirmiştir. Özellikle Müslüman nüfusun giderek artması neticesinde imamların

71 Lars Friedner, "Religion in Pubic Education-Sweden", http://www.unitrier.de/fileadmin/fb5/inst/IEVR/Arbeitsmaterialien/Staatskirchenrecht/Europa /Konferenz_2010/Sweden.pdf, (05.12.2015), s.2.

72 Ibid.

73 Jareborg, ss.683-684.

74 Ibid, s.674.

75 Ibid.

76 Friedner, "İsveç, Din Devlet İlişkisi: Hukuki Yap1, Dini Kurumlar, Din Eğitimi ve Din Hizmetleri”, s.475.

77 Svenska Kyrkan, "Ministry and Ministries". 
eğitimi bir tartışma konusu olmuş ve 2009 y1linda "Devlet ve İmamlar: Din, Bütünleşme ve Otonomi (The State and Imams: Religion, Integration and Autonomy)" isimli bir resmi rapor hazırlanmıştır. Raporun temel amac1 devletin imamların eğitimine müdahil olup olmaması gerektiğini araştırmaktır. Raporda devletin böyle bir adım atmasının dini topluluklara karşı sergilediği tarafsızlığa zarar vereceğinden endişe edildiği bu nedenle eğitimin devlet kontrolünde değil dini toplulukların karar alanında olması gerektiği belirtilmiştir. ${ }^{78}$

\section{Toplumsal Alanda Din ve Devletin Müdahale Alanı}

Nüfusun çoğunun Evanjelik Lüteryen olduğu İsveç’te diğer dinlere ve mezheplere mensup insanlar da göz önüne alındığında halkın \%65'i bir dini topluluğun üyesidir. ${ }^{79}$ Ancak WVS'nin 2011 yllı verilerine bakıldığında kiliseye veya bir dini topluluğa "aktif" olarak üye olduğunu belirtenlerin oranı $\% 5,6$ olup bu oranın en yüksek olduğu yaş aralığ $\% 6,9$ ile 50 yaş üzeridir. ${ }^{80}$

Kültürel çeşitliliğin söz konusu olduğu İsveç’te bu çeşitliliğin toplumsal düzlemdeki yansımalarına bakıldığında, farklı inançlara sahip bireylere hoşgörü ve sayg1 göstermek önemlidir. WVS'nin 2011 verilerine göre İsveçliler arasında "çocuklara öğretilmesi gereken önemli niteliklerden biri hoşgörü ve saygıdır" diyenlerin oranı \%87'dir. ${ }^{81}$ Aynı araştırmada "kabul edilebilir tek din benim inandığım dindir" cümlesine "hayır" diyenlerin oran1 \%27,9; "kesinlikle hayır" diyenlerin oranı ise \%58,5'tir. Yine katılımcılara farklı inançtan biriyle komşu olmak isteyip istemedikleri sorulduğunda sadece \%3,7'si bunu istemeyeceğini

78 Clemens Cavallin, "After the State Church: A Reflection on the Relation Between Theology and Religious Studies in Contemporary Sweden", Journal for the Study of Religions and Ideologies, Cilt:10, Say1:29, 2011, s.49.

79 World Values Survey, s.16.

80 Aynı araştırmaya göre halkın \%55,8’i evlilik ve cenaze dışında dini toplantılara aktif olarak hiç katılmadığını belirtmiştir. Bu toplantılara yalnızca resmî tatil günlerinde katıldı̆̆ını ifade edenlerin oranı ise \%7,1'dir. Bu durum halkın dini cemaatlere aidiyetini ve dolayısıyla davranış biçimi değerlendirmek bakımından önemlidir. Örneğin bir siyasi parti söz konusu olduğunda aktif olarak üye olduğu belirtenlerin oranı \%87; 30 yaş altındakilerde ise \%90, 4’tür. Detaylar için bknz: World Values Survey, s.16.

81 World Values Survey, s.3. 
belirtmiştir. 2013 yllında Gavle Üniversitesi tarafindan yürütülen "Çeşitlilik Barometresi (Diversity Barometer)" isimli bir çalışmaya göre ise dini eğitim veren okullar başta olmak üzere İsveçlilerin bazı dini unsurlara şüpheyle yaklaştığını; buna rağmen nüfusun \%74'ünün etnik ve kültürel çeşitliliğge olumlu baktı̆̆ını söylemek mümkündür. ${ }^{82}$

İnanca bağlı tercihlerin toplumsal yaşamdaki yansımaları devletin bu alana ilişkin önlemlerine de bağlıdır. Ayrımcıllk Kanunu ${ }^{83}$ (Discrimination Act, SFS 2008:567)'nda her türlü ayrımcllıla mücadele etmek ve din, dil, cinsiyet, yaş vb. unsurlar ayırt etmeksizin eşit muameleyi sağlamak bir amaç olarak belirtilmektedir (Madde 1). Ayrımcillk Kanunu'na göre bireylerin dini veya mezhepsel tercihlerine yönelik tutumlar ayrımcılık türleri içinde sayılmaktadır (Madde 4). Ayrımcılığa karşı alınacak tedbirlerin yer aldığ1 bölümde işyerinde ve eğitim alanında inanca ilişkin hükümler de yer almaktadır. Örneğin işçi ile işveren arasındaki ilişkiden bahsederek işverenler ile işçilerin işyerinde din, etnik köken gibi unsurlar üzerinden ayrımcılıkla mücadele etmek ve eşit muameleyi sağlamak adına her türlü tedbiri almaları ve iş birliği yapmaları gerektiği ifade edilmektedir (Bölüm 3 Madde 1). Aynı bölümde yüksek öğrenim dahil olmak üzere her türlü eğitimde öğrencilerin hiçbir ayrımcillğa maruz kalmaması gerektiği de belirtilmektedir (Madde 14).

Toplumsal yaşamda inanç özgürlüğünün yerini sorgularken nüfusun çoğunluğun bağlı olduğu ve dolayısıyla toplumsal pratiklerin şekillenmesinde baskın bir rolü olan İsveç Kilisesi'nin bu alandaki politikalarının da irdelenmesi gerekmektedir. XIX. yüzyılın ortalarından bu yana demokratikleşme yönündeki çabalarını sürdüren İsveç Kilisesi'nin toplumsal dinamiklere ve değişimlere uyum sağlayan bir politikaya sahip olduğunu söylemek mümkündür. 2013 y1lında Uppsala Başpiskoposu olarak seçilen ve hala görevde olan Antje Jackelén İsveç'in ilk kadın başpiskoposu olarak tarihe geçmiştir. 8 Eylül 1988 tarihinde Avrupa İnsan Hakları Mahkemesi'nde görülen bir dava Kilise'nin kadın din görevlilerine yaklaşımı bakımından önemlidir. İsveç Kilisesi’ne bağlı

82 Sweden-Sverige, “Ten Fundementals of Religion in Sweden”.

83 "Discrimination Act",

http://www.su.se/polopoly_fs/1.10243.1292582081!/menu/standard/file/Discri minationAct_English.pdf, (04.08.2015) 
bir rahip olarak görev yapan Jan Åke Karlsson, 1984 yllında Lund Piskoposluğu tarafindan açılan bir yöneticilik pozisyonuna başvurmuştur. Ancak inancı nedeniyle, kadınların din görevlisi olarak atanmasına karşı olduğu bilinen Karlsson'a, bir kadın din görevlisi ile birlikte çalışı çalışamayacağı sorulduğunda bu sorunun bir varsayıma dayandığını belirterek karşı çıkmış ve görevini elinden gelen en iyi biçimde yerine getirebileceğini ifade etmiştir. Mülakat neticesinde Kilise tarafindan başvurulan Karlsson'ın pozisyona uygun nitelikte bir aday olmadığı belirtildiğinde Karlsson din, vicdan ve ifade özgürlügünün ihlal edildiği gerekçesi ile konuyu AİHM'e taşımıştır. AİHM ilgili kararında halihazırda Kilise'ye bağlı bir din adamı olarak görev yapan Karlsson'ın bu göreve atanmasında inançlarının engel yaratmadığı; inancı nedeniyle görevine son verilme tehlikesi yaşamadığ1; başvurduğu pozisyonun yöneticilik görevi olması nedeniyle altındaki din görevlileri ile çalışabilme koşulunun haklı olduğu yönünde karar almış ve davayı reddetmiştir. ${ }^{84}$

Kilise'nin eşcinsel evliliklere ilişkin tutumu da onu diğer dini topluluklardan ayırmaktadır. 1 Mayıs 2009 ylında İsveç'te yasallaşan eşcinsel evliliğe ilişkin olarak 2009 yılında Kilise Meclisi tarafından bir komite raporu ${ }^{85}$ yayınlanmış ve komite Kilise bünyesinde eşcinsel evliliklerin yapılabileceğini; bunun Kilise tüzüğüne ve işleyişine dahil edilmesi gerektiğini belirtmiştir. Kilise Meclisi'nde yapılan oylamada 251 üyeden 176's1 lehte oy kullanmış ve Kilise içinde bu uygulama başlamıştır. ${ }^{86} 2009$ yılından bu yana İsveç Kilisesi'nde 5375 eşcinsel evlilik gerçekleştirilmiştir. ${ }^{87}$

\section{Sonuç}

İsveç'te devletin Kilise'ye ve diğer dini topluluklara olan tutumu yüzyıllar süren tarihsel bir sürecin neticesinde şekillenmiştir. 1850’lerden bu yana devlet, dini kurumlarla olan ilişkisinde mutlak bir birlikten tarafsız ve seküler bir devlet anlayışına doğru hareket etmektedir. Reform

84 European Court of Human Rights, "Karlsson vs. Sweden", http:/ / hudoc.echr.coe.int/eng?i=001-249 (16.12.2015)

85 Svenska Kyrkan, "Church Synod Liturgy Committee Report 2009:2-Wedding and Marriage”, https://www.svenskakyrkan.se/default.aspx?id=587144, (16.12.2015)

86 Pettersson, s.125.

87 Sweden-Sverige, "Ten Fundementals of Religion in Sweden". 
sürecinde Kilise ile hükümetler arasında tanık olduğumuz müzakereler ve Kilise'nin karar alma mekanizmalarına hâkim olan demokratik anlayış İsveç'i diğer ülkelerden farklı kılmaktadır. Bunun yanında, diğer ülkelerde karşılaştığımızın aksine, reform sürecinin dini otorite ile siyasi otorite arasındaki güç paylaşımı üzerinden değil inanç özgürlüğü temelinde ilerlemiş olması İsveç’i din-devlet ilişkisinde özgün bir vaka kılmaktadır.

2000 yllında yürürlüğe giren reformlar sonrasında devletin dini topluluklara yaklaşımında eşit muamele ilkesini gözettiğini söylemek mümkündür. Zira devlete ait birimler hibe ve aidatlara ilişkin desteğinin dışında dini toplulukları herhangi bir şekilde denetlememektedir. Yine de devletin İsveç Kilisesi ile arasındaki ilişkiye bakıldığında taraflar arasındaki tarihsel bağın getirdiği farklı bir ilişki biçimi olduğu görülmektedir. Reform hareketleri ile bağımsız ve demokratik bir yapıya dönüştürülen Kilise İsveç'in toplumsal yaşamındaki etkisi ve halkın çoğunun Evanjelik Lüteryen olması nedeniyle dominant rolünü devam ettirmektedir. Buna devletin Kilise'nin statüsü ve faaliyetlerine ilişkin tutumunun neden olduğunu düşünenler de mevcuttur. Cenaze ve defin işlemlerinde temel sorumluluğun hala İsveç Kilisesi'nde olmasi; Kilise'ye sağlanan devlet desteğindeki prosedürün farklılaşması yahut kültürel mirasın korunmasına ilişkin verilen destek bu anlamda eleştirilere maruz kalmaktadır. Kraliyet ailesinin Evanjelik Lüteryen olması ve bu mezhebe göre yetiştirilmeleri hükmü ise devlet politikası için açık bir istisnadır. Tüm bu nedenlerle Kilise ile devlet arasindaki mevcut durumun tam bir ayrılık olmadığını söylemek mümkündür. Dolayısıyla, dinin bireyselleşmesi ve devlete ait alanlardan çekilmesi bakımından modern devlet unsurlarını barındıran ve sekülerleşme kuramına uygun bir vaka gibi görünen İsveç, geleneksel dini pratiklerin toplumsal yap1 içindeki işlevselliğini önemli ölçüde koruması nedeniyle istisnai bir durum da sergilemektedir.

İsveç Kilisesi ile devlet arasındaki ilişkinin durumu ve reformların yeterliliği sorgulanırken devletin diğer dini topluluklara karşı izleyeceği politika da son zamanlarda dikkatle izlenmelidir. Son yıllarda yoğun biçimde ve farklı coğrafyalardan göçmenlere ev sahipliği eden İsveç’te dinsel çeşitlilik artmakta; sosyal ve kamusal alanda dini simgeler ve pratikleri daha görünür hale gelmektedir. Bu durum İsveç halkının uzun yıllar içinde geliştirdiği dini pratikleri özel alanda yaşama alışkanlı̆̆1 ve 
devletin dini meselelere uzak ve tarafsız kalma politikası için bir sınama niteliğindedir. 


\section{KAYNAKÇA}

Beckman, Ninna Edgardh, Thomas Ekstrand, Per Pettersson. "The Church of Sweden as an Agent of Welfare - the case of Gävle", Churches in Europe as Agents of Welfare - Sweden, Norway and Finland (ed. Anne Birgitta Yeung), SLU Repro, Uppsala, 2006, ss.20-85.

Casanova, José. "Rethinking Secularization: A Global Comparative Perspective", The Hedghog Review, Say1 8, 2006, ss.7-22.

Cavallin, Clemens. "After the State Church: A Reflection on the Relation Between Theology and Religious Studies in Contemporary Sweden", Journal for the Study of Religions and Ideologies, Cilt:10, Say1:29, 2011, ss.43-63.

Chaves, Mark. "Secularization as Declining Religious Authority", Social Forces, Cilt 72, Say1 3, 1994, ss.749-774.

Dobbelaere, Karel. "Some Trends in European Sociology of Religion: The Secularization Debate", Sociological Analysis, Cilt 48, Say1 2, 1987, ss.107-137.

Edqvist, Gunnar. "Freedom of Religion and New Relations Between Church and State in Sweden", Studia Theologica - Nordic Journal of Theology, Cilt:54, Say1:1, 2000, ss.35-41.

Gustafsson, Göran. "Church-state Separation Swedish-style", West European Politics, Cilt:26 Say1:1, 2003, ss.51-72.

Hughey, Michale W. "The Idea of Secularization in the Works of Max Weber: A Theoretical Outline", Qualitative Sociology, Cilt 2, Say1 1, 1979, ss.85-111.

Jareborg, Maarit Jantera. "Religion and the Secular State in Sweden", 18th Annual Congress of the International Academy of Comparative Law, 2010, https://www.wcl.american.edu/journal/genderlaw/19/191.cfm, (05.08.2015), ss.669-686.

Kam Markollegiet, "Registration of Religious Communities", http://www.kammarkollegiet.se/english/registration-religiouscommunities, (06.12.2015). 
Lars Friedner, "Religion in Pubic Education-Sweden", http://www.unitrier.de/fileadmin/fb5/inst/IEVR/Arbeitsmaterialien/Staatskirc henrecht/Europa/Konferenz_2010/Sweden.pdf, (05.12.2015).

Lars Friedner, "İsveç, Din Devlet İlişkisi: Hukuki Yapı, Dini Kurumlar, Din Eğitimi ve Din Hizmetleri”, AB Ülkelerinde Din-Devlet İliskisi Sempozyumu Kitabı, İslam Araştırmaları Merkezi, İstanbul, 0910.12.2006, s.471-488.

Ministry of Culture-Sweden, "Changed Relations between the State and the Church of Sweden", http://www.sst.a.se/download/18.4c1b31c91325af4dad3800015 $546 / 1377188428760 /$ Fact + sheet+about+statechurch+relations.pdf, (04.08.2015).

Pettersson, Per. "State and Religion in Sweden: Ambiguity Between Disestablishment and Religious Control", Nordic Journal of Religion and Society, Cilt:24, Say1:2, 2011, ss. 119-135.

SST- Nämnden för statligt stöd till trossamfund,

"SST in English", http://www.sst.a.se/inenglish.4.7f968fc211eeec933de800011945. html, (04.08.2015).

"Act on Church of Sweden", http://www.sst.a.se/download/18.4c1b31c91325af4dad3800015 541/1377188428904/Act+on+Church+of+Sweden+Act.pdf , (04.08.2015).

"Act on Religious Communities Signatures", http://www.sst.a.se/download/18.4c1b31c91325af4dad3800015 529/1377188428875/Act+on+religious + communities.pdf, (04.08.2015).

"Ordinance on Registration of Religious Communities", http://www.sst.a.se/download/18.4c1b31c91325af4dad3800015 $537 / 1377188428821 /$ Ordinance + on +Registration + of + Religions +Communities.pdf, (04.08.2015).

"Act on Support to Religious Communities", http://www.sst.a.se/download/18.4c1b31c91325af4dad3800015 
531/1377188428850/Act+on+support+to +religious + communit ies.pdf, (04.08.2015).

"Act on Fees to Registered Religious Communities", http://www.sst.a.se/download/18.4c1b31c91325af4dad3800015 535/1377188428890/Act+on+Fees+to+Registered+Religious + Communities.pdf, (04.08.2015)

Statistcs "Pweden, "Population Statistics", http://www.scb.se/en_/finding-statistics/statistics-by-subjectarea/population/population-composition/population-statistics/, (06.12.2015).

Stockholms Universitet, "Discrimination Act", http://www.su.se/polopoly_fs/1.10243.1292582081!/menu/sta ndard/file/DiscriminationAct_English.pdf, (04.08.2015).

Svenska Kyrkan,

"Church History", https://www.svenskakyrkan.se/churchofsweden/church-history, (04.08.2015).

"Church

and State", http://www.svenskakyrkan.se/churchofsweden/church-andstate, (04.08.2015).

"Church Synod Liturgy Committee Report 2009:2-Wedding and Marriage", https://www.svenskakyrkan.se/default.aspx?id=587144, (16.12.2015)

"Ministry and Ministries", https://www.svenskakyrkan.se/churchofsweden/ministry-andministries, (04.08.2015).

"Welcome to the Church of Sweden", https://www.svenskakyrkan.se/english, (04.08.2015).

Sveriges Riksdag,

"The Instrument of Government", http:/ /www.riksdagen.se/Global/dokument/dokument/laws/T he-Instrument-of-Government-2015.pdf, (19.11.2015). 
"The Freedom of the Press Act", https://www.riksdagen.se/Global/dokument/dokument/laws/ The-Freedom-of-the-Press-Act-2015.pdf, (19.11.2015).

"The Act of Succession", https://www.riksdagen.se/Global/dokument/dokument/laws/t he-act-of-succession-2012.pdf, (19.11.2015).

Swatos, H., Jr. and Kevin J. Christiano, "Secularization Theory: The Course of a Concept", Sociology of Religion, Cilt 60, 1999, ss.209228.

Sweden-Sverige, "Ten Fundementals of Religion in Sweden", https://sweden.se/society/10-fundamentals-of-religion-insweden/, (06.12.2015).

Wilson, Bryan R. "Aspects of Secularization in the West", Japanese Journal of Religious Studies, Cilt 3, Say1 4, 1976, ss. 259-276.

World Values Survey, "World Values Survey (2010-2014)-Sweden 2011", http://www.worldvaluessurvey.org/WVSDocumentationWV6.js p, (15.09.2015). 